\title{
Clearance of micronutrients during continuous renal replacement therapy
}

\author{
Nuttha Lumlertgul ${ }^{1,2,3}$, Danielle E. Bear ${ }^{1,4}$ and Marlies Ostermann ${ }^{1 *}$ (D)
}

Malnutrition is common in critically ill patients with acute kidney injury (AKI), especially if renal replacement therapy (RRT) is needed. There are several potential explanations, including nutrient losses during RRT. Although previous studies confirmed that micronutrients were detectable in effluent fluid [1-4], daily losses have not been formally quantified. In addition, information about the transport characteristics of individual micronutrients during RRT is lacking.

We recently measured serial plasma concentrations of vitamins, trace elements, carnitine and 22 amino acids (AAs) for up to six consecutive days in 55 critically ill adult patients with severe AKI [5]. The main findings were that patients treated with continuous renal replacement therapy (CRRT) had significantly lower plasma concentrations of citrulline, glutamic acid and carnitine at $24 \mathrm{~h}$ after enrolment and significantly lower plasma glutamic acid concentrations at day 6 compared to nonCRRT patients. In $>30 \%$ of CRRT patients, the plasma nutrient concentrations of zinc, iron, selenium, vitamin $D_{3}$, vitamin $C$, tryptophan, taurine, histidine and hydroxyproline were below the reference range throughout the 6-day period.

Loss of nutrients into the effluent fluid depends on their plasma concentration $\left(C_{\mathrm{p}}\right)$, sieving coefficient (SC) and dose and duration of RRT. The SC describes a solute's permeability across the dialysis membrane and depends on molecular size, electric charge (Donnan equilibrium), protein binding, volume of distribution, filter porosity,

*Correspondence: Marlies.Ostermann@gstt.nhs.uk

1 Department of Critical Care, King's College London, Guy's \& St Thomas' NHS Foundation Trust, 249 Westminster Bridge Road, London SE1 7EH, UK Full list of author information is available at the end of the article contact time and adsorption to the membrane. It is calculated from the ratio of effluent to plasma solute concentration $\left(\frac{\left[C_{\text {eff }}\right]}{\left[C_{\mathrm{pl}}\right]}\right)$. A SC less than one represents a mass transfer process where the concentrations have not equilibrated.

Here, we report the SCs and daily total losses of AAs, vitamins, trace elements and carnitine of all 33 CRRT patients recruited to the study mentioned above [5]. Total daily loss was calculated as $C_{\mathrm{pl}} \times \mathrm{SC} \times$ effluent volume per day. In addition, we estimated total losses for standard CRRT at $25 \mathrm{ml} / \mathrm{kg} / \mathrm{h}$ for $24 \mathrm{~h}$. Table 1 lists the SCs for all important nutrients and average daily losses during CRRT for up to 6 days. The key findings are:

1 Despite small molecular weights, the SCs of nutrients varied.

2 The SC of all but 2 AAs was below 1 indicating incomplete equilibration during RRT. Hydroxyproline had the highest SC (6.63). The exact reasons for SCs greater than 1 are not clear and warrant further investigations.

3 The absence of small-molecule water-soluble vitamin B1, B6 and B12 in the effluent was unexpected. However, we note that $\mathrm{Oh}$ et al. reported similar findings and speculated that dilution by the effluent, conversion to alternative metabolites not discriminated by mass spectrometry or adsorption by the hemofilter may have contributed [1].

4 The high daily losses of carnitine, vitamin $\mathrm{C}$ and trace elements in the effluent were consistent with reports in the literature [2-4].

Nutrition in AKI is an under-researched area, and the role of routine micronutrient supplementation in original author(s) and the source, provide a link to the Creative Commons licence, and indicate if changes were made. The images or other third party material in this article are included in the article's Creative Commons licence, unless indicated otherwise in a credit line to the material. If material is not included in the article's Creative Commons licence and your intended use is not permitted by statutory regulation or exceeds the permitted use, you will need to obtain permission directly from the copyright holder. To view a copy of this licence, visit http://creativecommons.org/licenses/by/4.0/. The Creative Commons Public Domain Dedication waiver (http://creativeco mmons.org/publicdomain/zero/1.0/) applies to the data made available in this article, unless otherwise stated in a credit line to the data. 
Table 1 Mean sieving coefficient and daily loss of amino acids, vitamins and trace elements

\begin{tabular}{|c|c|c|c|c|c|}
\hline Nutrient & $\begin{array}{l}\text { Molecular weight [g/ } \\
\mathrm{mol}]\end{array}$ & Mean $\mathrm{SC}^{\mathrm{a}} \pm \mathrm{SE}$ & $95 \% \mathrm{Cl}$ & Daily loss ${ }^{\mathbf{b}}[\mathrm{mg}]$ & $\begin{array}{l}\text { Standardized } \\
\text { daily lossc } \\
{[\mathrm{mg}]}\end{array}$ \\
\hline Alanine & 89.1 & $1.02 \pm 0.03$ & $0.95-1.09$ & $1102.3 \pm 98.4$ & $603.7 \pm 37.2$ \\
\hline Arginine & 174.2 & $0.99 \pm 0.04$ & $0.91-1.07$ & $427.9 \pm 42.4$ & $237.6 \pm 16.3$ \\
\hline Aspartic acid & 133.1 & $0.82 \pm 0.07$ & $0.67-0.97$ & $32.9 \pm 2.3$ & $20.3 \pm 1.9$ \\
\hline Citrulline & 175.2 & $0.93 \pm 0.05$ & $0.82-1.03$ & $756.0 \pm 45.3^{*}$ & $439.4 \pm 24.9^{*}$ \\
\hline Glutamic acid & 147.1 & $0.53 \pm 0.03$ & $0.47-0.60$ & $208.71 \pm 17.3$ & $118.4 \pm 7.4$ \\
\hline Glutamine & 146.2 & $0.96 \pm 0.03$ & $0.90-1.01$ & $2525.9 \pm 172.8$ & $1397.3 \pm 68.1$ \\
\hline Glycine & 75.1 & $0.89 \pm 0.03$ & $0.82-0.96$ & $558.1 \pm 39.8$ & $317.4 \pm 20.1$ \\
\hline Histidine & 155.2 & $0.83 \pm 0.02$ & $0.78-0.87$ & $387.9 \pm 27.7$ & $216.4 \pm 12.1$ \\
\hline Hydroxyproline & 131.1 & $6.63 \pm 0.83$ & $4.94-8.31$ & $224.7 \pm 28.6$ & $131.3 \pm 18.5$ \\
\hline Isoleucine & 131.2 & $0.94 \pm 0.02$ & 0.89-0.99 & $373.9 \pm 35.2$ & $206.9 \pm 13.1$ \\
\hline Leucine & 131.2 & $0.81 \pm 0.02$ & $0.76-0.86$ & $592.5 \pm 57.8$ & $330.2 \pm 21.9$ \\
\hline Lysine & 146.2 & $0.88 \pm 0.03$ & $0.83-0.94$ & $968.1 \pm 90.3$ & $535.4 \pm 38.6$ \\
\hline Methionine & 149.2 & $0.90 \pm 0.03$ & $0.83-0.97$ & $182.5 \pm 19.4$ & $100.0 \pm 8.1$ \\
\hline Ornithine & 132.2 & $0.70 \pm 0.02$ & $0.66-0.74$ & $291.1 \pm 28.5$ & $161.4 \pm 11.2$ \\
\hline Phenylalanine & 165.2 & $0.91 \pm 0.03$ & $0.85-0.96$ & $626.1 \pm 57.8$ & $349.6 \pm 25.1$ \\
\hline Proline & 115.1 & $0.75 \pm 0.02$ & $0.71-0.79$ & $558.4 \pm 47.7$ & $308.0 \pm 21.4$ \\
\hline Serine & 105.1 & $0.96 \pm 0.04$ & $0.88-1.04$ & $339.3 \pm 24.4$ & $196.8 \pm 9.9$ \\
\hline Taurine & 125.2 & $0.77 \pm 0.08$ & $0.62-0.93$ & $124.4 \pm 2.2$ & $71.1 \pm 12$ \\
\hline Threonine & 119.1 & $1.00 \pm 0.03$ & $0.95-1.06$ & $496.8 \pm 43.7$ & $276.4 \pm 20.0$ \\
\hline Tryptophan & 204.2 & $0.55 \pm 0.03$ & $0.49-0.61$ & $128.1 \pm 11.9$ & $72.8 \pm 4.9$ \\
\hline Tyrosine & 181.2 & $0.96 \pm 0.02$ & $0.91-1.01$ & $554.5 \pm 51.9$ & $307.3 \pm 20.9$ \\
\hline Valine & 117.1 & $0.88 \pm 0.02$ & $0.84-0.93$ & $895.5 \pm 81.7$ & $499.4 \pm 29.6$ \\
\hline Carnitine & 161.2 & $0.92 \pm 0.04$ & $0.83-1.01$ & $1698.0 \pm 134.7^{*}$ & $981.9 \pm 75.8^{*}$ \\
\hline Vitamin B1 & 265.4 & UD & UD & UD & UD \\
\hline Vitamin B6 & 169.2 & UD & UD & UD & UD \\
\hline Vitamin B12 & 1355.4 & UD & UD & UD & UD \\
\hline Vitamin C & 176.1 & $0.83 \pm 0.07$ & $0.69-0.98$ & $100.5 \pm 15.3$ & $59.0 \pm 9.2$ \\
\hline Vitamin D2 & 397 & UD & UD & UD & UD \\
\hline Vitamin D3 & 384.6 & UD & UD & UD & UD \\
\hline Copper & 63.6 & $0.009 \pm 0.002$ & $0.006-0.013$ & $0.33 \pm 0.05$ & $0.20 \pm 0.03$ \\
\hline Iron & 55.8 & $0.02 \pm 0.01$ & $0-0.04$ & $0.07 \pm 0.02$ & $0.04 \pm 0.09$ \\
\hline Folate & 441.4 & $0.51 \pm 0.03$ & $0.44-0.58$ & $59.9 \pm 11.7^{* *}$ & $35.3 \pm 6.9^{* *}$ \\
\hline Selenium & 79.0 & $0.036 \pm 0.02$ & $0-0.08$ & $0.04 \pm 0.01$ & $0.04 \pm 0.02$ \\
\hline Zinc & 65.4 & $0.10 \pm 0.07$ & $0-0.24$ & $0.67 \pm 0.20$ & $0.64 \pm 0.32$ \\
\hline
\end{tabular}

* $\mu \mathrm{mol} /$ day ${ }^{* *} \mu \mathrm{g} / \mathrm{day}$

SC sieving coefficient, SE standard error, $\mathrm{Cl}$ confidence interval, UD undetected

a SC was calculated as $\frac{\left[C_{\text {eff }}\right]}{\left.C_{\mathrm{pl}}\right]}$, where $C_{\text {eff }}$ is effluent concentration and $C_{\mathrm{pl}}$ is plasma concentration

b Daily loss (mg) was calculated by $C_{\mathrm{pl}} \times \mathrm{SC} \times$ effluent volume per $24 \mathrm{~h}$

c Standardized daily loss (mg) was estimated for CRRT dose $25 \mathrm{~mL} / \mathrm{kg} / \mathrm{h}$ for $24 \mathrm{~h}$

patients receiving CRRT is unknown [6]. Our data support future studies in this field. We acknowledge some limitations. First, we measured nutrient concentrations but did not investigate any relevant metabolic pathways and therefore cannot comment on the clinical impact of nutrient losses. Second, we only included patients who were established on full enteral nutrition and received CRRT for up to 6 days. Whether the results also apply to patients receiving parenteral nutrition or CRRT for longer periods is unclear. Finally, we are unable to make recommendations for nutritional support in clinical practice but suggest that intervention studies are urgently required. 


\section{Acknowledgement}

The authors would like to thank the investigators in the original study'Micronutrients in critically ill patients with severe acute kidney injury'for recruiting the patients, collecting the samples, performing the laboratory measurements of the micronutrients and data collection.

\section{Authors' contributions}

M.O. conceived and designed the manuscript. D.B. collected the original data, interpreted the results and contributed significantly to the manuscript. N.L. performed the analysis and drafted the manuscript. All authors revised the manuscript and approved the final version.

\section{Funding}

The study was partially funded through a research grant from the European Society of Intensive Care Medicine.

\section{Availability of data and materials}

The datasets used and/or analyzed during the current study are available from the corresponding author on reasonable request.

\section{Consent for publication}

Not applicable.

\section{Ethical approval}

The study was approved by the National Research Ethics Committee (13/ LO/0064). Written informed consent was obtained from all patients or legal representatives.

\section{Competing interests}

D.E.B reports speaker fees from Nutricia, Baxter Healthcare, B. Braun and Fresenius Kabi; advisory board fees from Baxter Healthcare, Fresenius Kabi, Abbott Nutrition, Cardinal Health and Avanos; and conference attendance support from B. Braun, outside the submitted work. All other authors report no conflicts of interest.

\section{Author details}

'Department of Critical Care, King's College London, Guy's \& St Thomas' NHS Foundation Trust, 249 Westminster Bridge Road, London SE1 7EH, UK.
${ }^{2}$ Division of Nephrology, Department of Internal Medicine and Excellence Center in Critical Care Nephrology, King Chulalongkorn Memorial Hospital, 1873 Rama IV Road, Bangkok 10330, Thailand. ${ }^{3}$ Research Unit in Critical Care Nephrology, Chulalongkorn University, 1873 Rama IV Road, Bangkok 10330, Thailand. ${ }^{4}$ Department of Nutrition and Dietetics, Guy's \& St Thomas' NHS Foundation Trust, 249 Westminster Bridge Road, London SE1 7EH, UK.

Received: 10 October 2020 Accepted: 14 October 2020

Published online: 19 October 2020

\section{References}

1. Oh WC, Mafrici B, Rigby M, Harvey D, Sharman A, Allen JC, Mahajan R, Gardner DS, Devonald MAJ. Micronutrient and amino acid losses during renal replacement therapy for acute kidney injury. Kidney Int Rep. 2019;4(8):1094-108.

2. Story DA, Ronco C, Bellomo R. Trace element and vitamin concentrations and losses in critically ill patients treated with continuous venovenous hemofiltration. Crit Care Med. 1999;27(1):220-3.

3. Berger MM, Shenkin A, Revelly JP, Roberts E, Cayeux MC, Baines M, Chioléro RL. Copper, selenium, zinc, and thiamine balances during continuous venovenous hemodiafiltration in critically ill patients. Am J Clin Nutr. 2004;80(2):410-6.

4. Zappitelli M, Juarez M, Castillo L, Coss-Bu J, Goldstein SL. Continuous renal replacement therapy amino acid, trace metal and folate clearance in critically ill children. Intensive Care Med. 2009;35(4):698-706.

5. Ostermann M, Summers J, Lei K, Card D, Harrington DJ, Sherwood R, et al. Micronutrients in critically ill patients with severe acute kidney injury: a prospective study. Sci Rep. 2020;10(1):1505.

6. Ostermann M, Macedo E, Oudemans-van Straaten HM. How to feed a patient with acute kidney injury. Intensive Care Med. 2019;45(7):1006-8.

\section{Publisher's Note}

Springer Nature remains neutral with regard to jurisdictional claims in published maps and institutional affiliations.
Ready to submit your research? Choose BMC and benefit from:

- fast, convenient online submission

- thorough peer review by experienced researchers in your field

- rapid publication on acceptance

- support for research data, including large and complex data types

- gold Open Access which fosters wider collaboration and increased citations

- maximum visibility for your research: over 100M website views per year

At BMC, research is always in progress.

Learn more biomedcentral.com/submissions 